\title{
Stalled Conflicts in the Mediterranean
}

\section{Neophytos Loizides (chapter 5)}

To be cited as:

Neophytos Loizides 'Stalled Conflicts in the Mediterranean', in Gillespie, Richard, and Frédéric Volpi, eds. Routledge Handbook of Mediterranean Politics. Routledge, 2017. pp: 171-181

For published version see:

https://www.routledge.com/Routledge-Handbook-of-Mediterranean-

$\underline{\text { Politics/Gillespie-Volpi/p/book/9781138903982 }}$

\section{Introduction}

This chapter examines contemporary conflicts and stalemates in the broader Mediterranean region. While emphasizing there is no single uniform model of a 'Mediterranean' conflict or stalemate, it points to a number of shared patterns and commonalities in such regional ethnopolitical issues as the Arab-Israeli, Balkan, Spanish/Catalan, Cypriot, Greek-Turkish, Kurdish, and post-Arab spring conflicts. Specifically, it asks why most peace-building projects have failed despite the visible involvement of European and international organizations and despite historical legacies of tolerance and accommodation in the Mediterranean region. Focusing on intra-state conflict, it argues that dominant groups have been reluctant to accommodate diversity, preferring to maintain mutually hurtful and destructive stalemates. To shed light on this puzzling pattern, the chapter cites recent failures to accommodate diversity, showing how dominant nationalisms have used negative demonstration effects and false analogies from the past to constraint attempts at political accommodation. 


\section{Political Accommodation and Stalled Conflicts}

Stalled conflicts in the Mediterranean particularly intra-state conflicts are explicitly linked to failures in embracing political accommodation including for instance federal or consociational models. ${ }^{1}$ This is a paradox as historically, the region even its most conflictual eastern part has hosted a multiplicity of popular federal movements and nationalist ideologies, for example, among the Balkan nations (Stavrianos 1959), the Southern Slavs (Banac 1983, 1984), Macedonians (Rossos 2008), Greeks and Turks (Anagnostopoulou 1997; Veremis 1989), Israeli and Palestinians (Yiftachel 2006) and pan-Arab nationalists (Ajami 1978; Dawisha 2003).

Looking at the devastating civil wars in the post-Arab spring era, it is difficult to imagine the strength of pan-Arab nationalism a few decades earlier. The United Arab Republic was a popular but short-lived manifestation of this failed project. Other potentially federalizable Mediterranean sub-regions have also failed, as for instance, the long-dreamed-of federation among the Balkan people, or more specifically, among South Slavs, including Habsburg and Ottoman Štokavian speakers; the latter dialect 'united' the Serbo-Croat-Bonsiak linguistic world and set the stage for the political union of the South Slavs. Nonetheless, when the former Yugoslavia fell apart, this particular section did not manage to maintain its 'federal unity' despite a shared language and rich intellectual traditions. While western media initially pointed to its ethnic diversity as a cause of its violent breakdown, this argument seems limited. For instance federalism was equally short-lived among the 'ethnicallyrelated' Serbs and Montenegrins (Ramet 2006). Likewise, the attempt to federalize Libya in three main provinces lasted only for about a decade (1951-1963). Following Muammar Gaddafi's take-over in 1969, federal options between Libya and its 
neighbors were negotiated, first with Egypt and Syria and then with Tunisia, but both attempts ended in acrimony (Dawisha 2003).

Meanwhile, early consociational attempts in the Mediterranean region's smaller multiethnic states, including Cyprus (Kyriakides 1968; Markides 1977) and Lebanon (Zahar 2005; Dekmejian 1978) led to similarly violent breakdowns. Both cases commonly feature as major examples of unsuccessful consociationalism in the relevant literature (Schneckener 2000; Lijphart 1996). The Cyprus stalemate is particularly puzzling, as reunification talks have failed to reach a comprehensive settlement despite a signed agreement on bicommunal administration since 1977-79, strong pro-federalist positions embraced by at least three main political parties in the island (i.e. AKEL, DISY and CTP), and the proactive involvement of international and regional organizations including the United Nations and the European Union (Richmond 2005; Anastasiou 2008; Ker-Lindsay 2011).

In another telling case, Turkey could have mitigated its own stalled conflict with its Kurdish minority through political accommodation in the form of decentralization. In the Turkish as well as the Egyptian cases, we could point to the large population as an important pre-existing enabling condition for decentralisation . Both current stalemates could, in theory, be addressed by introducing 'informal' federal or consociational arrangements, as in South Africa, Singapore or Spain, to regulate conflict with territorial and non-territorial minorities. Instead, the AK Party has governed Turkey with little formal or informal power-sharing with either Kurds or rival Kemalist political parties. Likewise, in post-Mubarak Egypt, the choice of a (majoritarian) presidential system has deepened the conflict between supporters of the Muslim Brotherhood and the military, reversing the brief achievements of the Arab Spring. Tunisia, on the contrary opted for proportional parliamentary democracy 
mitigating the conflicts between political Islam and secularism.

\section{Perceptions of Stalemates and Political Accommodation}

In addressing stalled conflicts, "hawks" usually draw from grievances, hatred, and security dilemmas (Jervis, 1978; Kaufman, 2011; Petersen, 2011), while "doves" point to mutually-hurting stalemates and opportunities for compromise through some form of political accommodation (Zartman, 1989; McGarry 2011; Heraclides, 2001). Perceptions are central in evaluating the claims of each camp. A prevalent perception in the region is that power-sharing is unnecessary because people have been living in peace and harmony for ages. Integrationist and assimilationist programs downplaying ethnic differences are common, particularly in left-wing political movements. By emphasizing a "mythical peaceful past" and "unity over minority rights", leftist movements have restricted, even undermined, federal and consociational prospects. Perceptions challenging the very existence of minorities, let alone their rights, are fundamental to the region's protracted conflicts and stalemates. Even if individuals are welcome as equals in nation-building, cultural rights are violated.

Historically, the failure of the Arab unity project could be attributed to its emphasis on 'unity' rather than 'diversity;' in principle, diversity could have been accommodated using federal and consociational devices. This is also true for Turkey and its Kurdish minorities but applies equally well to Shiite versus Sunni conceptions of Arab unity (and their respective fears). Other cases in the region, particularly those in Spain (Catalans and Basques) and Italy (South Tyrol) suggest the viability of an alternative route. Mediating power-sharing requires explicit (constitutional) commitments to minorities that the achievement of 'national unity' will not preclude diversity. Credible constitutional arrangements should aim to safeguard minorities 
from the loss of autonomy or representation while majorities should be protected from dysfunctional constitutional provisions and secession. The major advantage of federal and consociational arrangements is that they frequently offer the most credible way to address security, financial or identity risks, while combining shared goals with separate spheres of government for majorities and significant minorities. Likewise, power-sharing, either through guaranteed group representation in the central government or through territorial decentralization and federalism, could be understood as a form of 'compensation' for groups likely to resist a 'hegemonic' or assimilationist state, as they will now have a vested interest in the power-sharing structure.

In both Yugoslavia and the Arab-speaking world, attempts at state-building have failed to balance the tensions between unity and diversity, leading to disintegration and conflict. In the case of Iraq, Dawisha argues these tensions became evident during the peak of Arab nationalism in 1958 following the July 14 coup and the emergence of rival parties. For the 'Iraq First Group', issues of preserving diversity across ethnic and religious lines were critical: 'Arab Unity was seen as a Sunni project designated to ensure the ultimate subjugation of the non-Sunni communal groups' (Dawisha 2003:219). He adds that the Iraqi First group 'was not necessarily averse to some form of union, but theirs was a much looser conception than that held by the nationalists, at most a federal arrangement in which Iraq would retain considerable autonomy’ (ibid: 216). A similar pattern emerged in Syria, eventually resulting in the failure of the larger Arab unity project (ibid).

For their part, South Slav federal/state-building projects fell short of balancing regional/federal autonomy with national solidarity. Using the term 'flawed unification,' Banac (1984:13) says Yugoslavia failed to meet the promise of its 
intellectual founding fathers. This was particularly true in interwar Yugoslavia, originally called the Kingdom of Serbs, Croats and Slovenes. According to Ramet, its component peoples 'came to the kingdom with rather different expectations and for different reasons' (2006:37). Like Kurds in Iraq today, Croats and Slovenes sought security, aligning with the new Kingdom to protect themselves from further territorial losses to Italy but also hoping for a federal constitution (ibid). But Serbian elites assumed political, economic and cultural hegemony within the new state, adopting strict centralism. And as in the pan-Arab case, 'the policy of monopolizing the top posts in the country for Serbs was at the minimum, politically insensitive likely to give provocation, and short-sighted' (Ramet 2006:37).

The general insistence on integration/assimilation largely explains the conflict trajectory in the Mediterranean region. For instance, Iraqi centralists downplayed crimes against Kurds by attributing these exclusively to the Saddam Hussein regime. Turkish nationalists, mostly on the left, voice similar arguments when discussing their own Kurdish national minorities, attributing crimes to previous regimes. Yet since the mid-1990s, the Turkish left has found limited support among the Kurdish minority. Even after the election of a moderate leader from the region, Kemal K1lıçdaroğlu, as President, the main opposition party, CHP (Republican People's Party), won only a tiny fraction of its votes in Kurdish regions, thus failing to create a new platform from which to transcend the stalemate.

\section{Stalemates and Failing Political Settlements}

A second dominant perception of stalled conflicts is that multi-ethnic states are prone to failure. This is particularly true of (but not limited to) those espousing right-wing nationalisms, which frequently see any recognition of ethnic or religious diversity as a 
stepping-stone to secession. Right-wing nationalisms have a particularly strong attachment to power, authority and territory, frequently treating sovereignty in a nonnegotiable manner while attributing conflicts with their minorities to external interference.

In the narratives of most Middle East and Balkan nationalisms, territories 'won or kept with blood' are not in any sense renegotiable through federal or consociational arrangements. Unsurprisingly, then, remembrance of fallen soldiers is a central theme in the region's official discourses, as demonstrated, for instance, in Turkey's stance on PKK casualties in the 1990s (Navaro-Yashin 2002: 118). Parliamentary debates are telling; for instance, in his 1995 speech to the Turkish Grand National Assembly, conservative President Süleyman Demirel remembered with compassion all Turkey's 'martyrs and our teachers who have become victims of terrorism while trying to educate our children through great self-sacrifice'(Loizides, 2016: 216). And even though Recep Tayyip Erdoğan initially attempted to accommodate Kurdish minority rights, he eventually adopted the major principles of Turkish conservative nationalist ideology.

Elsewhere in the region, various contemporary political parties have drawn their inspiration from national liberation movements, as in Croatia (HDZ), the Republic of Macedonia/FYROM (VMRO-DPMNE), Cyprus (DISY among Greek Cypriots, UBP among Turkish Cypriots) and Lebanon (Kataeb Party), to mention only a few. Yet these political parties have shown elements of adaptation in the past decade, suggesting that power-sharing is not necessarily incompatible with right-wing (or left-wing) ideologies. Center-right political actors often develop effective and credible ties with external peace actors, such as the European Union. Similar processes of positive adaptation towards moderation can also occur in leftist political 
traditions. For instance, in Spain, the left has traditionally supported power-sharing arrangements with Catalans and Basques, often against the wishes of right-wing opposition, while in Cyprus, several impressive mobilizations by the Turkish Cypriot left have demonstrated a clear desire to transcend the Cyprus stalemate.

While encouraging, such breakthroughs remain few and far between. Political parties seldom reach consensus in issues of power-sharing, as moderate parties frequently face ethnic outbidding by intra-ethnic rivals. In the presence of dominant nationalist perceptions, it is easier for the masses to adopt political views uncritically and act in ways that strengthen existing elite consensus, thus creating a vicious cycle between public expectations and the viability of federal or consociational projects. Even moderate elites may shy away from promising peace settlements, if they perceive them as politically risky or unfeasible. Arguably, a reassuring international environment for political accommodation might enable domestic actors to reassess their positions. In the end, we are left wondering whether power-sharing fails because external actors actively work against it or because domestic forces have not acted preemptively to neutralize destructive outside influences - or both.

\section{'Power-sharing is destructive'}

A third common perception is that power-sharing cannot resolve issues of multiethnicity. A core understanding driving the current Syrian crisis is that federalism and consociationalism have devastating effects and could worsen ethnic and religious conflicts. For the most part, critics say power-sharing in various forms has failed in the region. The relatively recent examples of Lebanon, the former Yugoslavia and post-1960 Cyprus have consolidated the view of federalism and consociationalism as dysfunctional, if not catastrophic. Sadly, the region lacks an indisputably successful 
consociational or federal model which could inspire others to follow suit. Looking at the period between World Wars I and II, Ramet points out that while Norway and Finland in Europe provided models of what newly independent states could be, there was no similar model for the Balkans (2006:3). More recently in Iraq, external and domestic critics alike have emphasized the absence of a relevant federal example. For instance, Muslim religious leaders, as well as 'liberal and democratic' politicians, have stressed the need to preserve the country's unity and have frequently 'urged the Kurds not to rush into formulae like federalism and confederalism with which the region is not familiar' (Mideast Mirror 2004; emphasis added). As argued elsewhere (Loizides 2016), Ottoman institutions and religious legacies of tolerance preserved cultural diversity for centuries; despite their embedded hierarchical nature, they could have provided the political and cultural antecedents for federal and consociational arrangements. But the reading of the Ottoman past is frequently limited to brief references in national history books and is highly selective.

In fact, how elites publically frame the millet legacy in post-Ottoman successor states makes the public endorsement of federal and consociational arrangements difficult, if not impossible. Through a series of false analogies, contemporary critics compare recent minority accommodation proposals in the form of power-sharing or community recognition to the millet system and its role in the violent collapse of the Ottoman Empire (Berkes 1963). One example is Sonyel's Minorities and the Destruction of the Ottoman Empire (1993), published by the Ataturk Culture, Language and History Foundation, an institution devoted to the preservation of Kemalist thought in Turkey. Such perceptions preclude any discussion of federalism, in either the official Turkish Republican ideology or the broader majority discourses in the country, including AKP's counter-hegemonic positioning. 
Thus, despite the general liberalization since the 1990s of Turkish discourse on domestic and regional identity representation (Somer 2005; Fokas 2008), institutional transformation through power-sharing does not feature in the political discourse. Instead, Turkey has moved towards an increasingly majoritarian (semi-presidential) system and will fully endorse presidentialism in the near future.

State institutions play a central role in maintaining hegemonic perceptions on political accommodation, particularly when confronted with contrary examples from other parts of the world, including Spain, as mentioned earlier. After visiting Spain in 1993, for instance, Turkish PM Tansu Çiller allegedly proposed the use of the Basque model to solve the conflict in Kurdish regions, something she later denied (Pope 1993: 14). Her rival and ANAP successor Mesut Yilmaz rejected the idea of federation with the Kurds and stated that regional cultures in Turkey must be allowed to exist through their own means (TRT TV 1992). On another occasion, Yilmaz said the Kurdish language should become the second official language in Turkey, but this proposal was eliminated before any debate could take place (McDowall 1997: 428).

More recently, in early 2007, a Turkish prosecutor initiated a criminal inquiry against former President and coup leader Kenan Evren for even suggesting Turkey should become a federation. Drawing on his early proposal for administrative regions, Evren had spoken openly in the media, suggesting Turkey would one day decide on federalism; otherwise, 'there will be no peace', he said, adding that the ten per cent election threshold obstructed Kurds from getting into Parliament (Turkish Daily News 2007). Not surprisingly, reactions were overwhelmingly negative, with some attributing to the former General's comments to insanity.

\section{Protracted Stalemates: Alternative Explanations}


Lack of political accommodation and stalled conflicts in the Mediterranean region are also driven by structural conditions. There is for instance significant variation in external intervention strategies and other structural conditions across historical and contemporary conflicts in the Mediterranean region, including size, regime type, natural resources and level of economic development. Structural factors certainly contribute to the emergence and implementation of federal and consociational settlements, but no easily identifiable set of structural conditions is shared by most cases presented here.

As noted above, alternative accommodation formulas have failed despite historical institutional precedents, ethnic or linguistic affinities, and major external incentives, as demonstrated in the last few decades by the European Union's intervention in 2004 Cyprus. Another factor in understanding stalemates and political accommodation in the Mediterranean region is the impact of colonial rule. While acknowledging this factor, it is important to consider the experience of other countries before reaching any conclusions. For one thing, the success of federal arrangements is not confined to industrial nation-states out of which no federation has failed since WWII (Bermeo 2002). For another, in much of the developing world, successful federations and consociations have survived and even thrived in volatile regional environments. These include a number of former colonies, such as India, Nigeria, Brazil, Ethiopia, South Africa and Indonesia, whose socioeconomic and political conditions, arguably, are similar to those in the Middle East or the post-Ottoman Balkans. Thus, explanations emphasizing colonial effects might not adequately account for the nature of stalled state-building in the region. Faced with comparable challenges, other post-colonial leaders, for example, in India, have successfully countered colonial legacies by embracing political secularism and federal 
accommodation that offered symmetrical treatment to the various religious and ethnic communities across the country (Kohli 2004). In contrast, it could be argued that in the eastern part of the Mediterranean, coercive power-sharing has turned the region's 'early advantage' of tolerance into an unfortunate demonstration of how federalism and consociationalism can lack prospects or viability.

Finally, it is useful to draw comparisons with post-communist societies in the Balkans as well. Critics of power-sharing in the region claim ethno-federalism facilitates nationalist mobilization and state disintegration (Bunce 1999). For Bunce, the design of these systems puts into place virtually all of the building blocks necessary for the rise of nationalist movements (ibid: 49). This process seems confined to communist federations, although a similar argument could be made for authoritarian regimes in the Middle East. In Yugoslavia, Stefanovic identifies the problem as the country's centralism, not federalism. He argues that 'despite its formal federal character, the centralized organization of the Communist Party, which wielded political and economic power, insured that Yugoslavia was a unitary state' (forthcoming). He concludes: 'Communist Yugoslavia was not a genuine federation as the communist federations were federal in form but unitary in content' (ibid; emphasis added; see also Connor 1984; McGarry 1998).

\section{Transcending Stalled Conflicts}

Despite their 'federal and consociational failures' some of the successor states of the former Yugoslavia, including Bosnia, Kosovo and the Republic of Macedonia/ FYROM (like Lebanon) returned to such arrangements in the absence of alternatives and in the search for more genuine and viable forms of power-sharing. These states are already seeing some success: decreased violence, reduced international 
involvement in peacekeeping commitments, and return in some areas of internally displaced persons. Admittedly, federalism and consociationalism are difficult to effectuate in prolonged stalemates, especially as these areas might resort to federalism or power-sharing when it is too late - too much blood has been shed in the past, and any central authority or shared institutions including political parties have been absent.

Yet a supporting international intervention could be the key in transcending the obstacles facing these renewed power-sharing projects. To cite few examples, Bosnia has at least partially avoided the fate of other post-conflict societies in the region where lines of division were perpetuated with almost zero returns. And powersharing provisions in the Republic of Macedonia/ FYROM prevented renewed violence after the short 2001 war despite predictions to the contrary.

A key lesson from these cases, for instance a potentially federal or decentralized Syria, is that the later should combine decentralization with powersharing at the centre (consociationalism). A consociational arrangement will ensure that the future government of Syria would be fully representative of the country's ethnic, linguistic and religious identities. A government of national unity inclusive of all democratically elected groups will prevent secessionist demands as all legitimate groups will feel represented in decision-making. Power-sharing will prevent situations where a territorially significant group becomes consistently excluded/ostracized from the central government. Such groups often respond with secession following attempts by others to ostracize them politically during negotiations to form a government. In environments of low inter-ethnic trust as in Syria, a constitutional formula has to be in place to ensure inclusivity, proportionality and functionality. 
External peace allies and credible incentives are also critical in socializing undecided actors to overcome stalemates and accept a peace settlement compromise. Yet external mediation and power-sharing institutions could be designed to better accommodate domestic political parties and their needs. And as demonstrated in the broader literature, external intervention works best in areas where indigenous leadership has been extensively engaged in decision-making and implementation (Dahlman \& Ó Tuathail 2005; Bieber 2006; Belloni 2008 and Stefanovic \& Loizides 2011).

\section{Conclusions}

This chapter reaches three conclusions in its analysis of stalemates in the Mediterranean region. First, traditions of elite accommodation and past legacies matter. On the one hand, they can sustain power-sharing arrangements (Daalder 1974; Lijphart 1977), but on the other, they can act as barriers to such arrangements if negative memories, nationalist narratives and false analogies prevail in the public discourse. Although contemporary federal and power-sharing models differ greatly from the Ottoman Empire's millet system, the communist Yugoslavia or the postcolonial arrangements created for Cyprus and Lebanon, these cases sustain discourses negating contemporary attempts for political accommodation; they also constrain recent institutional innovations which could potentially overcome the stalled Mediterranean conflicts.

Second, certain core features mark the stalled conflicts in the Mediterranean countries. Majority nationalisms in the region have confronted ethnic and religious diversity not only by eliminating differences through ethnic cleansing and genocide (commonly associated with both the Southern European and the post-Ottoman 
countries) but also by incorporating, even glorifying, diverse 'folklore' traditions provided these are adjusted to fit within the parameters of the dominant state nationalism (Hobsbawm 1992; Triandafyllidou 1998:606). In a nutshell, it is not surprising that the roots of many contemporary stalled conflicts from Morocco to Southeast Turkey and the former Yugoslavia lie not in exclusion and oppositional state-building programs but in ambitious efforts to forcibly integrate and assimilate unwilling 'half-brothers and sisters' (Stefanovic 2005).

Third, power-sharing and federalism could be appropriate antidotes to ongoing conflicts in this volatile region. This is particularly important for the current debates on the day after in Syria and Iraq. The Arab and South Slav unification projects discussed above are not the only cases in point. The essence of the Macedonian or Kurdish conflict in the $20^{\text {th }}$ century does not lie in the exclusiveness of neighboring nationalisms, but in the involuntary incorporation of 'brotherly communities' into narrowly defined centralized nationalist programs. In fact, recent examples from postwar Yugoslavia and elsewhere suggest that the appropriate institutional design could overcome ideational and structural barriers. As mentioned elsewhere, in most conflictual environments, the relative success of power-sharing should be understood in relation to previous records of civil strife (Loizides 2016). Following this reasoning, post-Franco Spain, post-Taif Lebanon, more recently, post-Arab Spring Tunisia and Morocco are 'relative success' stories (Zahar 2005; Bieber 2006; O’Leary 2005; Belloni 2008). These cases also suggest that there is no uniform pattern of conflict or stalemate in the Mediterranean region.

Admittedly, re-introducing power-sharing in difficult cases where previous experience has been negative might require major investment and support from outside actors, at least for a transitional period. In addition, related peace mediations 
require a deep understanding of the arguments of critics. It is essential to confront the arguments of those who oppose power-sharing and to design institutional arrangements that ease potential defects. Besides analyzing stalled conflicts and failures, we need to identify conflict-mitigating institutions that have been most effective under 'least likely' conditions. The 'transferability potential' of such institutional arrangements lies in their capacity to mitigate 'most difficult' conflict situations, setting the stage for comparable arrangements in similar or less complicated environments. A challenge for future research is identifying the key aspects of peace processes that could offer inspiration, especially in the most troubled countries in the Mediterranean region.

\section{References:}

Ajami, Fouad. 1978. “The End of Pan-Arabism” Foreign Affairs, 57(2): 355-373 Anagnostopoulou, Sia. 1997. Asia Minor, $19^{\text {th }}$ century -1919. The Greek Orthodox communities. From the Rum Millet to Greek nationhood" [IN Greek], Ellinika Grammata, Athens

Anastasiou, Harry. 2008. The Broken Olive Branch: Nationalism, Ethnic Conflict and the Quest for Peace in Cyprus. The Impasse of Ethnonationalism, Syracuse, NY: Syracuse University Press.

Banac, Ivo. 1983. “The Confessional 'Rule' and the Dubrovnik Exception: the Origins of the "Serb-Catholic Circle in the Nineteenth-Century Dalmatia," Slavic Review 42, (3): 448-74

Banac, Ivo. 1984. The National question in Yugoslavia: Origins History, Politics. Ithaca: Cornell University Press. 
Belloni, Roberto. 2008. State Building and International Intervention in Bosnia. London: Routledge.

Berkes, Niyazi. 1963. The Development of Secularism in Turkey, New York: Routledge.

Bieber, Florian. 2006. Post-war Bosnia: Ethnicity, Inequality and Public Sector Governance. New York: Palgrave Macmillan.

Bieber, Florian. 2006. Post-war Bosnia: Ethnicity, Inequality and Public Sector Governance. New York: Palgrave Macmillan.

Bunce, Valerie. 1999. Subversive Institutions: the Design and the Destruction of Socialism and the State, Cambridge: Cambridge University Press.

Burgess, Michael. 2006. Comparative Federalism in Theory and Practice, New York: Routledge.

Connor, Walker. 1984. The National Question in Marxist-Leninist Theory and Strategy Princeton: Princeton University Press.

Daalder, Hans. 1974. 'The Consociational Democracy Theme' World Politics, 26 (4): $604-621$

Dahlman, Carl and Gearóid Ó Tuathail. 2005. "The legacy of ethnic cleansing: The international community and the returns process in post-Dayton BosniaHerzegovina", Political Geography, 24 (5): 569-599

Dawisha, Adeed. 2003. Arab Nationalism in the twentieth century: From Triumph to Despair, Princeton: Princeton University Press.

Dekmejian, Richard Hrair. 1978. "Consociational Democracy in Crisis: The Case of Lebanon" Comparative Politics 10 (2): 51-65.

Fokas, Effie. 2008. "Islam in the framework of Turkey-EU relations: situations in flux and moving targets" Global Change Peace \& Security 20 (1): 87-98 
Heraclides Alexis. 2001. I Ellada ke o Ex Anatolon Kindynos [Greece and the Eastern Threat], in Greek, Athens: Polis Publishers.

Hobsbawm, Eric. 1992. “Introduction: Inventing Traditions”, In The Invention of Tradition by eds Eric Hobsbawm and Terence Ranger, 1-14. Cambridge: Cambridge University Press.

Hutchinson, John and Anthony Smith eds. 1994. Nationalism, Oxford: New York: Oxford University Press.

Jervis Robert. 1976. Perception and Misperception in International Politics, Princeton, N.J.: Princeton University Press.

Kaufman, Stuart J. 2011. "Symbols, Frames, and Violence: Studying Ethnic War in the Philippines'. International Studies Quarterly 55: 937-958.

Ker-Lindsay, James. 2011. The Cyprus Problem: what everyone needs to know, Oxford: Oxford University Press

Kohli, Atul. 2004. "India: Federalism and the Accommodation of Ethnic Nationalism" in Amoretti and Bermeo eds. pp. 281-301.

Kyriakides, Stanley. 1968. Cyprus: Constitutionalism and Crisis Government Philadelphia, University of Pennsylvania Press.

Lijphart, Arend. 1977. Democracy in Plural Societies: A Comparative Exploration, New Haven: Yale University Press.

Lijphart, Arend. 1996. "The Puzzle of Indian Democracy: A Consociational Interpretation". The American Political Science Review, 90 (2): 258-268.

Markides, Kyriakos. 1977. The Rise and Fall of the Cyprus Republic, New Haven: Yale University Press.

McDowall, David. 1997. A Modern History of the Kurds, London: I.B. Tauris. 
McGarry, John and Brendan O'Leary. 2005. Federation as a Method of Ethnic Conflict Regulation, Forum of Federations (available at www.forumfed.ca accessed online 18 October, 2012).

McGarry, John. 1998. “Orphans of Secession: National Pluralism in Secessionist Regions and Post-Secession States" in National Self-Determination and Secession ed. Margaret Moore ed. Oxford: Oxford University Press.

McGarry, John. 2011. "Centripetal Theory and the Cyprus Conflict”, paper presented at the Workshop on Power-Sharing, organized by the Ethnicity and Democratic Governance Project, Munk Centre, University of Toronto, 17 November.

Mideast Mirror. 2004. "The challenge of federalism in Iraq" January 23, accessed online through Nexis UK November 14, 2011.

O’ Leary, Brendan. 2001. “An Iron law of Nationalism and Federation? A (neoDiceyian) theory of the necessity of a federal Staatsvolk, and of consociational rescue", Nations and Nationalism, 7 (3): 273-296.

O’Leary Brendan. 2005. 'Power-sharing, Pluralist Federation, and Federacy'. In The future of Kurdistan in Iraq eds. Brendan O’Leary, John McGarry and Khaled Salih, 47-92. Philadelphia: University of Pennsylvania Press.

O’Leary, Brendan. 2002. "In Praise of Empires Past: Myths and Method of Kedourie's Nationalism”, New Left Review, 2, (18): 106-30.

Petersen, Roger D. 2011. Western intervention in the Balkans: the strategic use of emotion in conflict. Cambridge: Cambridge University Press.

Pope, Hugh. 1993. "Turkish army blocks moves to Kurdish reform,” The Independent, October 15, p.14. 
Ramet Sabrina. 2006. The three Yugoslavias: State-Building and Legitimation, 19182005 Bloomington: Indiana University Press.

Richmond, Oliver. 2005. "Shared Sovereignty and the Politics of Peace: Evaluating the EU's 'Catalytic' Framework in the Eastern Mediterranean”, International Affairs, 82 (1): 149-176.

Rossos, Andrew. 2008. Macedonia and the Macedonians: A History. Stanford: Hoover Institution Press.

Schneckener, Ulrich. 2002. "Making Power-sharing Work: Lessons from Successes and Failures in Ethnic Conflict Regulation”, Journal of Peace Research, 39 (2): 203-228.

Somer, Murat. 2005. "Resurgence and remaking of identity- Civil beliefs, domestic and external dynamics, and the Turkish mainstream discourse on Kurds", Comparative Political Studies, 38, (6): 591-622.

Stavrianos S. Leften. 1959. The Balkans since 1453 New York: Rinehart and Company.

Stefanovic, Djordje and Neophytos Loizides. 2011. The Way Home: Peaceful Return of Victims of Ethnic Cleansing, Human Rights Quarterly, 33 (3): 408-43.

Stefanovic, Djordje. 2005. "Seeing the Albanians through Serbian Eyes: The Inventors of the Tradition of Intolerance and their Critics, 1804-1939." European History Quarterly 35, (3): 465-92.

Triandafyllidou, Anna. 1998. "National Identity and the 'Other"” Ethnic and Racial Studies 21 (4): 593-612.

Turkish Daily News. 2007. Week in Review, March 10 (accessed online through Nexis UK November 14, 2011). 
Veremis, Thanos. 1989. "From the National State to the Stateless Nation 1821-1910", European History Quarterly, (19): 135-148.

Yiftachel, Oren. 2006. Ethnocracy: Land and Identity Politics in Israel/Palestine,

Philadelphia: University of Pennsylvania Press.

Zahar Marie-Joelle. 2005. "Power Sharing in Lebanon: Foreign Protectors, Domestic

Peace, and Democratic Failure" In Sustainable Peace: Power and Democracy

after Civil Wars eds. Donald Rothchild and Philip Roeder, 219-240. Ithaca:

Cornell University Press.

Zahar Marie-Joelle. 2005. "Power Sharing in Lebanon: Foreign Protectors, Domestic

Peace, and Democratic Failure" In Sustainable Peace: Power and Democracy

after Civil Wars eds. Donald Rothchild and Philip Roeder, 219-240. Ithaca:

Cornell University Press.

Zartman, William. 1989. Ripe for Resolution: Conflict and Intervention in Africa,

Oxford University Press.

\footnotetext{
${ }^{1}$ Consociationalism, among other key features, stipulates that power be shared by majorities and minorities, and it implies formal or informal veto rights for all parties (Lijphart 1977, McGarry and O'Leary 2005). Consociationalism involves powersharing at the center for instance through the collective presidency in Bosnia or the allocation of certain key posts to members of specific groups as in Lebanon.

Federalism refers to situations where authority is territorially divided between central and provincial governments, with both enjoying constitutionally separate competencies. Federations could be also consociations, as in Belgium and Switzerland, but not all federations are consociations, as in the United States and Australia. In addition, it could be argued that some federations function as semiconsociations, as in Canada and India. Semi-consociations include some elements of consociations but not others, for instance proportionality and community autonomy but no guarantees for long-term power-sharing or fully effective veto rights. There are also consociational agreements with territorially intermingled populations that do not take a federal form, such as post-1960 Cyprus, Lebanon, and Northern Ireland after the 1998 Good Friday Agreement. Power-sharing could take either territorial or nonterritorial forms through the inclusion of ethnic minority parties in the central government and guaranteed veto rights (see also Loizides 2016).
} 